\title{
O controle jurídico da omissão estatal pela norma da proporcionalidade
}

\author{
The legal control of state's omission by proportionality norm
}

\author{
Luiz Antônio Freitas de Almeida*
}

\section{Resumo}

\begin{abstract}
A norma da proporcionalidade, originariamente usada como padrão de controle jurídico no direito administrativo, foi importada desse ramo do direito para o direito constitucional, especialmente com o intuito de examinar e conter restrições excessivas aos direitos fundamentais. Se esse campo de aplicação da proporcionalidade encontra maior consenso no âmbito da doutrina e da jurisprudência, a parte menos explorada do seu uso está na sua adequação ou não para o escrutínio das omissões estatais, ou seja, verificar se houve um déficit de proteção por parte do Estado. Dessa forma, este artigo tem o propósito de defender a possibilidade de sindicar os deveres positivos do Estado pela norma da proporcionalidade, examinando sua estruturação e as modificações necessárias nos seus testes. Tal possibilidade de sindicância visa racionalizar essa tarefa, bem como posicionar-se sobre os diferentes campos de aplicação da proporcionalidade - como proibição do excesso e como proibição do defeito - e da articulação entre essas duas dimensões ou facetas da norma da proporcionalidade.
\end{abstract}

Palavras-chave: Proporcionalidade. Deveres Positivos e Omissão Estatal. Proibição do Deficit.

\section{Abstract}

The norm of proportionality, used, originally, as juridical control in administrative law, was also included in the constitutional law to examine and stop excessive restrictions to the fundamental rights. If this field of application of proportionality finds a consensus in the jurisprudence field, the least explored part of its use is in its suitability or not for the scrutiny of state omissions. In other words, is about to verify if there was or there was not a protection deficit from the State. Thus, this article aims to defend the possibility to syndicate the positive obligations of the State through the proportionality norm, examining its structuring and modification necessary to its tests. Therefore, this syndication possibility aims to rationalize this labor, as well to stand on different fields of the proportionality, as the excess prohibition itself, as a defect and articulation between these two dimensions and singularity of the proportionality norm.

Keywords: Proportionality. Positive Duties and State's Omission. Prohibition of the Deficit.

\section{Introdução}

Tradicionalmente, o princípio da proporcionalidade desenvolveu-se como instrumento metódico do raciocínio ponderativo no direito constitucional, sobretudo para aferir eventual excesso legislativo na restrição dos direitos fundamentais. Assim, seu uso foi engendrado dentro do controle de deveres estatais negativos, consistentes na obrigação de não intromissão ou de abstenção na liberdade individual protegida pelo direito fundamental. Seria, porém, uma ferramenta metódica viável para a sindicância do cumprimento dos deveres estatais positivos?

A importância desse debate insere-se na visualização de que há várias latitudes em que normas de direitos sociais foram positivadas como direitos fundamentais e não meramente como normas programáticas ou diretrizes sem justiciabilidade. Assim, ao contrário do silêncio eloquente dos textos constitucionais dos Estados Unidos e da Alemanha (praticamente) ou da positivação de direitos sociais como normas enfraquecidas, sem outorgar a competência de controle ao Judiciário (como é regra geral na Espanha), as Constituições brasileira, portuguesa, italiana e da África do Sul foram desenhadas com a previsão de direitos sociais como direitos fundamentais, a vincular o Parlamento, conferindo-se competência para o Judiciário exercer o controle de ações e omissões estatais.Destarte, avulta-se a importância desse debate, mormente, em sistemas jurídicos que contam com ingente fenômeno de judicialização de direitos sociais, como ocorre no Brasil especialmente com o direito à saúde.

(9) Doutor em Ciências Jurídico-Políticas e Mestre em Direitos Fundamentais pela Faculdade de Direito da Universidade de Lisboa, FUNL, Portugal. Especialista em Direito Constitucional pela Centro Universitário de Campo Grande mato Grosso do Sul, UNAES, MS, Brasil. Bacharel em Direito pela Universidade Federal de Mato Grosso do Sul, UFMS, MS. Brasil. Professor da Escola de Direito da Associação SulMato-Grossense dos membros do Ministério Público, MS, Brasil. Promotor de Justiça no Ministério Público de Mato Grosso do Sul. E-mail: lafalmeida12@gmail.com 
Por outro lado, diante de uma expansão do regime contemporâneo dos direitos fundamentais a várias democracias constitucionais, a norma da proporcionalidade tem obtido um entusiasmo de parte da doutrina, por percebê-la como uma ferramenta heurística que pode estruturar de forma mais completa o raciocínio ponderativo (KLATT e MEISTER, 2014, p. 2-8) Dessa forma, se ela não esvazia completamente os resquícios de subjetivismo, pode tornar as decisões as mais racionais possíveis. Logo, deve-se examinar, pois, a viabilidade de utilizar a norma da proporcionalidade para cumprir esse fardo metódico e, por outro lado, verificar se os passos analíticos ou testes que integram sua estrutura merecem ou não alguma adaptação para cumprir esse escopo.

Por fim, deve-se trabalhar uma eventual articulação da norma da proporcionalidade nas vertentes da proibição do excesso e na vertente da proibição do defeito, mormente para delimitar o campo de aplicação de cada parâmetro de controle.

Para tanto, o artigo guiar-se-á pelo método técnico-jurídico, com o recurso aos textos doutrinários e, eventualmente, aos enunciados normativos e a precedentes que sejam relevantes para o tema. Assumem-se marcos teóricos congruentes com a defesa da ponderação como método de decisão de conflitos normativos de princípios constitucionais, a exemplo de David Duarte, Robert Alexy, Mathias Klatt, Laura Clérico, Carlos Bernal Pulido e Aharon Barak.

\section{A existência dos deveres de proteção e a proteção contra a insuficiência de tutela}

A distinção clássica entre direitos de liberdade (ou direitos civis e políticos na nomenclatura internacional de direitos humanos) e direitos econômicos, sociais e culturais baseava-se na premissa de que, dos primeiros, derivavam-se obrigações de não interferência ou de abstenção estatal na esfera de liberdade; dos segundos, extraíam-se deveres ativos por parte do Estado, sobretudo de prestações materiais e normativas (LOEWENSTEIN, 1982, p. 398-402; BOBBIO, 2004, p. 20-21).

Contudo, a distinção clássica foi severamente abalada pela influência da dimensão objetiva dos direitos fundamentais. As constituições foram enriquecendo-se com uma nova gama de direitos, o que implicou um incremento de funções ao Estado, a ponto de diminuir ou esvaecer as linhas entre o público e o privado. A socialidade do Estado, buscada como forma de diminuir as desigualdades de base e ampliar as oportunidades individuais, ancorou a idealização de uma faceta objetiva (e não apenas um viés de direito subjetivo) a trazer funções até então não pensadas para os direitos fundamentais, como a extensão da eficácia de suas normas aos privados, a irradiação dessas normas aos demais ramos do Direito, a delimitação de uma competência negativa, independentemente da perspectiva jurídico-subjetiva do titular do direito e, aquilo que mais interessa ao presente artigo, um dever de proteção estatal contra as violações aos direitos fundamentais seja quem for o autor da conduta ilícita (MARTINS, 2005, p. 81-84; SARLET, 2007, p. 166-182; ALMEIDA, 2014, p. 149-153).

Indubitavelmente, o precedente mais impactante por descortinar alguns contornos da dimensão objetiva dos direitos fundamentais é o sumamente conhecido caso Lüth, decidido pelo Tribunal Constitucional Federal Alemão1.

O dever de proteção, no entanto, não se esgota na faceta de tutelar os titulares dos direitos fundamentais contra atentados praticados por particulares se a organização política estatal palmilhou para deixar a conotação meramente liberal do Estado do Direito. Na perspectiva de um Estado Social e Democrático de Direito, a temida sufocação da liberdade em tensão com as pretensões mais presentes de um Estado Social (FORSTHOFF, 1986. p. 76-88) deve ser corrigida pela compreensão das diferentes dimensões ou gerações dos direitos fundamentais como a complementarem-se, a fim de que a liberdade jurídica não seja sem sentido (BÖCKENFÖRDE, 1993a, p. 76-83). Dessa forma, sobretudo no Brasil, onde impera constitucionalmente o objetivo da República brasileira de reduzir as desigualdades sociais, ao dever de proteção acrescenta-se uma verdadeira obrigação de promoção dos direitos fundamentais ${ }^{2}$.

\footnotetext{
BVerfGe 7, 198, de 1958. O texto do acórdão está parcialmente reproduzido em SCHWABE, 2005, p. 381-395. Eric Lüth propôs, publicamente e na imprensa, um boicote aos filmes do diretor Veit Harlan por conta de um suposto envolvimento desse diretor com a propaganda nazista durante o período da segunda guerra. As pessoas jurídicas produtoras do filme e Harlan ingressaram com uma demanda cível, com pleitos de proibição do boicote, sob pena de multa ou prisão, o que foi deferido pelo Tribunal de Hamburgo. Lüth aviou, então, uma reclamação constitucional perante o Tribunal Constitucional Federal alemão, que reformou a decisão da corte inferior por entender violada a liberdade de expressão, fundamentando a decisão também com base na dimensão objetiva dos direitos fundamentais.

2 Alexy (2009, p. 50; 2008 p. 442 e seguintes), a propósito, menciona que o direito à ação positiva do Estado pode ser visto como um gênero, do qual se extraem os deveres de proteção, talhados para defender o titular perante a ameaça de terceiros particulares, os deveres de criação de organizações e procedimentos e os deveres de prestação em sentido estrito, o que não deixa de compreender um dever de promoção dos direitos sociais mediante prestações materiais. Como se percebe no texto, ao menos em ordenamentos onde os direitos sociais estejam positivados como direitos fundamentais e não haja diferença quanto à sua aplicabilidade comparativamente aos direitos de primeira dimensão, é viável usar a proibição do defeito também para sindicar o dever de promoção dos direitos fundamentais.
} 
Assumir essa postura teórica implica rejeitar a distinção tradicional entre direitos de liberdade ou de primeira dimensão e os direitos de segunda dimensão ou direitos econômicos, sociais e culturais, de sorte a proclamar um tratamento dogmático unitário, a descortinar nas diferentes normas de direitos fundamentais positivadas como princípios jurídicos a correlação de uma gama diversa de deveres ativos e negativos, liberdades e sujeições, independentemente da "geração" do direito fundamental (NOVAIS, 2010, p. 123-150; MATOS, 2010, p. 399-417; SILVA, 2011, p. 553-562) ${ }^{3}$. Em suma, todos os direitos fundamentais cuja natureza é principiológica exalam deveres negativos e positivos (ACHEAMPONG, 2001, p. 191; ROIG, 2009. p. 157; MICHELMAN, 2003, p. 16-17; SARLET, 2010, p. 1.034-1.038).

O mais famoso precedente a reconhecer um comando de proibição do déficit de proteção foi o caso do aborto II julgado pelo Tribunal Constitucional Federal Alemão, o qual se amparou na tese dos deveres de proteção que emanam dos direitos fundamentais ${ }^{4}$.

Todavia, o parâmetro da proibição do déficit ou do defeito, conquanto tenha sido derivado dos deveres de proteção, possui uma autonomia em relação a eles (CANARIS, 2009, p. 122-125; SILVA, 2012, p. 191; ALMEIDA, 2021, p. 317-340). Afinal, mesmo que não se repute lógico supor um cumprimento insatisfatório do dever de proteção, é forçoso reconhecer que, ordinariamente, as constituições não costumam dispor sobre o grau de eficiência da salvaguarda de proteção, de modo que há uma graduação inelutável na intensidade ou grau de cumprimento dos deveres de proteção. Portanto, correta está a percepção de Jorge Pereira da Silva sobre a inexistência de uma "coincidência ontológica" entre os deveres de proteção e a proibição do déficit ou da insuficiência de tutela; dessa forma o dever de proteção (aqui incluído também o dever de promoção) é comando cujo destinatário é o legislador, enquanto que o segundo é parâmetro de controle da satisfação dessa obrigação, encargo precípuo da instituição com competência para controle de constitucionalidade.

\section{As dimensões do controle de proporcionalidade: a proibição do excesso e a proibição do defeito}

Sintetizado o fundamento dos deveres de proteção e promoção dos direitos fundamentais, os quais, por sua vez, conclamam a proibição do defeito como parâmetro de controle da atuação estatal, é preciso desvelar a relação dessa vertente da proporcionalidade com aquela mais comumente estudada ou referida: o controle de proporcionalidade para coibir o excesso de intervenção do estatal.

De início, poder-se-ia debater se a proibição do defeito é ou não uma forma de controle de proporcionalidade. Isto é, haveria uma autonomia dogmática da proibição do defeito frente à proibição do excesso? $\mathrm{O}$ assunto é debatido entre os juristas e é possível minutar três correntes principais (ALMEIDA, 2021, p. 317-340): i) a proscrição ou proibição de insuficiência de tutela seria um padrão ou parâmetro de controle totalmente estranho ao da proibição do excesso, sem invocação da norma da proporcionalidade (NOVAIS, 2010, p. 223-237); ii) a tese da convergência estrutural plena entre proibição do excesso e proibição do déficit, de sorte que os subtestes de proporcionalidade na modalidade de proibição do defeito seriam replicáveis na proibição do déficit sem qualquer modificação estrutural, apenas adaptando o ângulo de exame. Assim sendo, o resultado apurado seria idêntico em qualquer ângulo de aferição, isto é, a conclusão seria uníssona seja na ótica da proibição do excesso, seja no prisma da proibição do defeito (DUARTE, 2018. p. 49-70; BARAK, 2012, p. 422-434). Barak parece ser adepto desta tese, pois não diferencia os testes; iii) a tese da divergência estrutural entre a proibição do defeito e a proibição do excesso. Portanto, a proibição do defeito seria componente de um "macroconceito" de proporcionalidade, porém com adaptações na estruturação dos subtestes (ALEXY, 2009, p. 66-84; CANARIS, 2009, p. 67; CANAS, 2014, p. 4; CLÉRICO, 2009, p. 327; KLATT e MEISTER, 2014, p. 806-811).

\footnotetext{
Em sentido contrário ao preconizado no texto, conferir MEDEIROS, 2010, p. 654-683; NABAIS, 1998, p. 994-1.008.

BVerfGE 2/90, julgado em 28/05/1993. Versão em inglês disponível no sítio eletrônico do Tribunal Constitucional Federal alemão (https://www. bundesverfassungsgericht.de/SharedDocs/Entscheidungen/EN/1993/05/fs19930528_2bvf000290en.html). O Legislativo Federal alemão aprovou leis em vários ramos do direito que tocavam no tema do aborto. No âmbito penal, o aborto foi previsto como não ilícito se realizado por médico após prévio aconselhamento da gestante por instituição oficialmente autorizada e em até doze semanas depois da concepção, independentemente de necessidade médica da gestante. Na seara previdenciária, o seguro saúde contemplou a situação do aborto feito nessas condições e, portanto mesmo sem prescrição por necessidade médica. O Tribunal reconheceu em parte a inconstitucionalidade das normas, em razão do modo como foram aprovadas, pois o legislador estava a apontar que o aborto seria lícito mesmo sem necessidade médica e ainda que fosse exigível outra conduta. O posicionamento que prevaleceu na Corte era de que o modelo de política criminal poderia não prever a punição penal mediante uma isenção de pena, mas jamais considerar o aborto, nessa hipótese, como algo lícito, não sendo também justificável a extensão do benefício previdenciário a essa situação.
} 
A primeira posição contende com a aplicação do princípio ${ }^{5}$ da proporcionalidade na apreciação do déficit de proteção estatal porque reputa que não é uma norma adequada para escrutinar as obrigações positivas dos direitos sociais. Isso porque Reis Novais, com foco especialmente na teoria dos princípios de Alexy, sustenta que o conceito de restrição alexyano, por depender de otimização fática, resultaria no elastério desmedido da obrigação estatal, a onerar sobremaneira o erário. Assim, toda e qualquer prestação seria dedutível do direito fundamental e o Estado sempre estaria em situação de restrição.

O segundo ponto da objeção reside no sopesamento de bens e interesses de conteúdo material com o princípio da separação de poderes e com a carência de recursos, o que não admitiria ponderação. No lugar de um controle de proporcionalidade, Reis Novais sustenta que o correto seria escrutinar a omissão para aferição de um mínimo social, sedimentado pela interpretação da dignidade humana e posto à prova por um teste de razoabilidade à maneira da Corte Constitucional da África do Sul. Com isso, haveria o descumprimento da proibição do defeito se a razoabilidade evidenciasse uma situação intolerável.

Há contrapontos suficientes para rejeitar a opinião de Reis Novais. Ora, em relação à controvérsia entre a definição de um suporte fático amplo e um suporte fático restrito, Reis Novais termina por sustentar um critério mitigado da teoria do suporte fático amplo para o controle da proibição do excesso, com o intuito de evitar uma ponderação recorrente que as teorias do suporte fático amplo impulsionam (NOVAIS, 2003, p. 390-437), o que se julga a melhor solução. Assim, se a prestação, diante de um critério de evidência, não integrar o âmbito de proteção do direito fundamental social, está excluída e não é necessário considerar que a omissão configurará uma restrição ao direito fundamental ${ }^{6}$.

Ademais, não se aceita que, por usar o controle de proporcionalidade, esteja em causa a comparação de realidades incomparáveis. Em primeiro lugar, há vozes a sustentar a necessidade de releitura da norma de separação de poderes (GARCIA, 2005, p. 991-996; ALMEIDA, 2011, p. 185-206), uma vez que ela não pode ter a mesma interpretação que possuía na feição liberal do Estado existente no início do constitucionalismo, havendo assim a previsão de competência de controle de constitucionalidade, inclusive das omissões. Se há um Estado Social -e o Estado Democrático de Direito não deixa de ser uma especificação do Estado Social (ALEXANDRINO, 2006, p. 202) -, a separação de poderes evoluiu para sedimentar uma distribuição de competências entre os Poderes do Estado que evite um desequilíbrio entre os Poderes.

Em relação ao segundo posicionamento, também não parece ser o melhor caminho. Com efeito, defender a convergência estrutural equivale asseverar que o resultado do exame de proporcionalidade, seja pelo ângulo da proibição do excesso, seja pela ótica da proibição do déficit, acabe por ser sempre o mesmo. Em outras palavras, caso o Legislativo, no cumprimento de um dever de proteção, aprovasse uma restrição de alguma liberdade jusfundamental de modo adequado, necessário e proporcional, teria consequentemente atendido o comando da proibição do excesso e da proscrição do defeito.

O problema da segunda tese é a pressuposição nem sempre clara que está na base da sua adesão: pensar que geram os mesmos resultados implica sustentar que o Legislativo não possui margem alguma de discricionariedade para desempenhar suas funções; isso representa afirmar que o Legislativo seria um "mero executor da constituição", sem dignidade política (BÖCKENFÖRDE, 1993b, p. 123-138)7. Dessa forma, o Parlamento não teria margem de ação discricionária alguma, havendo praticamente uma ação a ser efetuada, pois, do contrário, ela

5 A natureza jurídica da norma da proporcionalidade é tema de controvérsia e não é possível estender o debate a esse respeito, razão pela qual serão sumarizadas algumas posições principais: i) os adeptos da distinção qualitativa ou forte entre princípios e regras sustentam que a proporcionalidade é uma regra, uma vez que não entra em conflito com outros princípios e aplica-se sempre por subsunção (ALEXY, 2008, p. 117; SILVA, 2009, p. 167; VIDAL, 2013, 277-281); ii) os partidários de uma distinção quantitativa ou fraca entre princípios e regras tendem a defender a posição de que é um princípio jurídico, em razão da indeterminação estrutural da norma, a exemplo de David Duarte (DUARTE, 2009, p. 165; DUARTE, 2010, p. 58-60; ALMEIDA, 2021, p. 245 e seguintes); iii) há quem defenda que é um norma híbrida, com matizes de regra e de princípio: o subteste da idoneidade é mais próximo de uma regra, por não conclamar ponderações, ao passo que os subtestes da necessidade e da proporcionalidade em sentido estrito reclamam ponderações, o que os enquadra como princípios (CANAS, 2012, p. 888 e seguintes). Advoga-se a segunda corrente.

6 A teoria mitigada do suporte fático amplo, aceita por Reis Novais para os direitos de liberdade, permite afastar interpretações exageradas para os direitos fundamentais sociais, a exemplo, dado pelo próprio Reis Novais $(2010$, p. 230), de pinçar um direito prima facie à uma penthouse em Manhattan como conteúdo do direito à habitação. Sobre a dificuldade ou objeção de considerar a existência de uma restrição pelo inadimplemento de obrigações positivas decorrentes de normas de direitos sociais, há quem rejeite essa possibilidade (ALEXANDRINO, 2011, p. 191-203), embora seja possível apregoar que se trataria de uma intervenção restritiva, dentre de um conceito amplo de restrição (NOVAIS, 2003, p. 192-254). No entanto, essa objeção só permite defender a viabilidade de desenvolver um conceito diverso de restrição para trabalhar com as omissões totais ou parciais, que são objeto de aferição na proibição do déficit. A esse respeito, (ALMEIDA, L. 2014, p. 235-244).

7 Sem embargo, Böckenförde usa a crítica não para tratar da proibição do defeito ou das teses da congruência, mas para alfinetar o agigantamento do Judiciário frente ao Legislativo pela aceitação da dimensão objetiva dos direitos fundamentais, numa feição de constituição como "ordem fundamental" e não como "ordem marco". 
seria censurada constitucionalmente por ser excessiva à liberdade ou insuficiente para resguardar a salvaguarda de proteção (ALEXY, 2009, p. 70; CANARIS, 2009, p. 119-128; CANAS, 2012, p. 872-873; SILVA, 2012, p. 193201; ALMEIDA, 2021, p. 317-340).

Finalmente, é viável rejeitar a tese da congruência estrutural com a ideia de que é possível logicamente visualizar situações em que houve a desatenção a um dever de proteção sem qualquer ação excessiva por parte do Estado, a exemplo de desastres naturais ou de ação praticada por um Estado estrangeiro (CANAS, 2017, p. 953-960; ALMEIDA, 2021, p. 317-340).

É forçoso admitir que o Parlamento dispõe de um espaço maior para conformação da proteção e promoção dos direitos fundamentais em comparação ao que possui para restringi-los, o que encontra explicação no exame analítico dos próprios deveres derivados das normas de direitos fundamentais.

Entrementes, no tópico antecedente já se pontuou que se orienta pela viabilidade de um tratamento dogmático unitário de todos os direitos fundamentais, o que implica a percepção da extração de deveres positivos e negativos das normas que tenham substância de princípios jurídicos. Porém, dessa premissa não decorre que haja uma homogeneidade estrutural entre os deveres negativos e positivos.

Deveras, há uma assimetria entre os deveres negativos e positivos, pois os deveres negativos possuem uma estrutura conjuntiva, ao passo que os positivos possuem uma estrutura disjuntiva (ALEXY, 2009, p. 54-55; CANARIS, 2009, p. 65-66 e 119-128; KLATT, 2014, p. 87-89; SILVA, 2012, p. 193-201; ALMEIDA, 2019, p. 205207; ALMEIDA, 2021, p. 317-340). Isso significa que, para os primeiros, reconhece-se a inconstitucionalidade de toda e qualquer ação positiva do Estado que gere real ou potencialmente o resultado vedado constitucionalmente. Contrariamente, nos deveres positivos, a inconstitucionalidade da omissão pode ser sanada não por uma única e específica ação, uma vez que existem alternativas capazes de satisfazer em maior ou menor grau o comando constitucional; assim, não se pode compelir o destinatário da norma a usar todas elas, a não ser que houvesse enunciados normativos constitucionais dos quais se extraíssem normas menos indeterminadas, a diminuir a margem de conformação da autoridade destinatária da norma de direito fundamental.

Tenha-se em mente, por exemplo, o direito à vida. O dever negativo principal do conteúdo desse direito é a proibição prima facie ${ }^{8}$ que seria dirigida ao Estado do ato de matar o titular do direito e, dentro de inúmeras possibilidades de ação viáveis para alcançar esse resultado, todas as alternativas estão proscritas de início. Reversamente, os deveres positivos de proteção em amplo sentido do conteúdo desse mesmo direito implicam inúmeras alternativas, mas nem todas elas são exigíveis constitucionalmente (é possível pensar em ações normativas de criminalização do homicídio, em prestações materiais, como a prestação de socorro para evitar a morte, na organização de instituições e procedimentos os mais variados possíveis, como a montagem de um aparato policial para proteger a vida das pessoas). Destarte, o dever negativo possui um oposto definitivo, o que não sucede com o dever positivo, que, em regra, não o possui (ALEXY, 2009, p. 45-55). Logo, a violação de um dever positivo pode ocorrer, entre as várias condutas ativas capazes de satisfazer a pretensão que the é correlacionada, por uma omissão total ou uma omissão parcial que resulte na proteção deficitária dada pelo Estado.

Por conseguinte, filia-se ao terceiro campo de pensamento, ou seja, é necessário realizar adaptações na estrutura formal da proporcionalidade, o que será levado adiante na seção seguinte.

\section{A estrutura formal da proporcionalidade para a proibição do déficit ${ }^{9}$}

Em primeiro lugar, deve-se conceder que a digressão sobre a estrutura da proporcionalidade não é algo simples como a princípio possa parecer. Há problemas das mais variadas ordens já na própria estrutura da proibição

8 Na lição de Duarte (2018, p. 54-55), o caráter prima facie da norma de direito fundamental representa: i) qualquer variável de conduta ou comportamento correlativo ao direito fundamental está contida no seu conteúdo; ii) a proteção outorgada pela norma de direito fundamental é provisória, porque depende do resultado da ponderação feita em conflitos normativos. Contudo, se aceita sem reserva apenas a segunda observação, eis que, em relação à primeira, adota-se a teoria do suporte amplo mitigado proposto por Novais. Remete-se à nota de rodapé n. 6 .

9 Um passo analítico necessário e distinto do exame de proporcionalidade é o da definição da intensidade de controle e da distribuição do ônus de prova e da carga de argumentação, etapa dissociada dos subtestes da proporcionalidade, muito embora influencie o resultado alcançado pelos subtestes. Assim, não se concorda com Alexy quando ele propõe a possibilidade de conflito e ponderação entre os princípios materiais e formais (2002 p. 28-58). É inviável discorrer sobre isso, tema que mereceria um artigo próprio, em razão dos limites de espaço do texto. Sobre a questão, conferir KLATT e MEISTER, 2014, p. 109-148; PIRKER, 2013, p. 61-84. Como orientação geral, sustenta-se que ordinariamente o padrão de controle guiar-se-á por uma versão débil dos testes de idoneidade e necessidade, embora seja possível, conforme justificação a cargo da instituição controladora, apresentar regras complementares para fortalecer esses subtestes e não relegar tudo para última etapa. A respeito dessas regras complementares, checar CLÉRICO, 2009, p. 101-161. 
do excesso e não há margem para tratar de todos. Assim, o escopo deste subtópico é pincelar apenas as principais diferenças e modificações necessárias na proporcionalidade para sindicar as omissões.

Antes de abordar esse tema, pontua-se uma primeira questão, que interessa a ambas as vertentes da proporcionalidade: o número de subtestes que derivam desse princípio jurídico. A esse respeito, as principais posições divergem entre uma estrutura bipartida (somente idoneidade e adequação, a excluir o exame da proporcionalidade em sentido estrito), tripartida (exames de idoneidade ou adequação, necessidade e proporcionalidade em sentido estrito) e quadripartida (legitimidade do meio e do fim, idoneidade, necessidade e proporcionalidade em sentido estrito (ALMEIDA, 2021, p. 265-267).

Com efeito, Pieroth e Schlink (2008, p. 81-87) sustentam que seria necessário retirar o escrutínio da proporcionalidade em sentido estrito, diante da irracionalidade da ponderação aí efetuada, não sendo lícita a substituição da ponderação do legislador pela ponderação judicial. No entanto, percebe-se que a crítica é mais dirigida à viabilidade de um juízo ponderativo exercido pelo Judiciário ${ }^{10}$, razão pela qual não será apreciada aqui.

Mais interessante do que filiar-se a uma concepção tripartida, que é majoritária na doutrina, ou quadripartida, é perquirir se a legitimidade do meio e do fim é um componente apreciado pela estrutura da proporcionalidade. Afinal, há defensores da corrente tripartida que examinam a legitimidade dos meios e dos fins dentro da etapa da adequação (CLÉRICO, 2009, p. 39-84; PULIDO, 2007, p. 693-723).

Por um lado, os que rejeitam que a legitimidade dos meios e dos fins seja um componente do exame da proporcionalidade sustentam que ela é um pressuposto lógico ao seu exame, isto é, um raciocínio prévio ao exame da proporcionalidade da restrição (e, acrescenta-se, da omissão). Nesse sentido caminham Bousta (2007, p. 863), Canas (2012, p. 10), Grimm (2007, p. 388) e Novais (2011, p. 167).

Deveras, embora haja bastante coerência no fundamento apresentado por esses juristas, entende-se que integrar a legitimidade dos meios e dos fins como etapa componente do próprio exame de proporcionalidade enriquece sua estrutura e dogmaticamente é sustentável pela própria finalidade da divisão em passos analíticos do exame, ou seja, aumenta a racionalidade da tomada de decisão por não olvidar de nenhuma etapa importante que deve ser avaliada. Assim, como explicado em ALMEIDA (2021, p. 266-278), caminha-se na trilha dos que incluem a legitimidade do fim como etapa integrante da proporcionalidade, a exemplo de Pavcnik e Lachmayer (2010, p. 161-167), Rivers (2006, p. 181) e Sweet e Mathews (2008, p. 75-79).

Um segundo ponto - o qual não será objeto de aprofundamento nesse tocante, mas que é comum à proibição do defeito e à interdição do excesso - é a possibilidade de diminuir os particularismos resultados pelo exame ponderativo caso se acople ao teste de proporcionalidade a estratégia de categorizar precedentes e intensidade de controle conforme o tipo de direito fundamental atingido pela ação ou omissão, na esteira do que preconiza Novais (2003, p. 897-954), embora este esteja a pensar somente na proibição do excesso.

Passando às alterações na estruturação do teste de proporcionalidade para coibir a insuficiência de tutela estatal, verifica-se, de plano, que a relação meio-fim, normalmente apregoada para a proibição do excesso, é de natureza causal, ao menos nas etapas da idoneidade e necessidade. Ou seja, se um meio é idôneo, é porque ele empiricamente causa o fim pretendido pelo Estado ou ao menos dá algum contributo fomentador; se ele for necessário, é porque não há alternativas que promovam o fim na mesma intensidade e, por sua vez, sejam menos agressivas ao conteúdo do direito fundamental. No entanto, Barak (2012, p. 131-174) já advertia que a visualização em todos os casos de uma relação meio-fim no aspecto causal seria redutora. Clérico (2009, p. 173) acerta quando constata que o exame de proporcionalidade em sentido estrito prescinde de uma relação meio-fim de natureza causal no sentido mais estrito da palavra, sendo possível construir uma relação de meio-fim em amplo sentido, por correspondência. Em sentido análogo, posiciona-se Grimm (2007, p. 393) ao afirmar que o exame da relação meio-fim é restrito aos testes da idoneidade e da adequação, não alcançando a proporcionalidade em sentido estrito na práxis do Tribunal Constitucional Federal Alemão.

Contudo, no controle da insuficiência de proteção estatal, não é possível estritamente sustentar uma relação meio-fim de natureza causal. Naturalisticamente falando, a omissão não causa um resultado, razão pela qual, no âmbito do direito penal, sustenta-se que o resultado punido por normas de crimes omissivos impróprios é imputado ao agente que se omitiu a título normativo, em razão de uma apreciação valorativa da conduta omissiva e pela não

10 Deveras, a discussão sobre a possibilidade jurídica de utilizar a ponderação como critério de solução de conflitos normativos é ampla e foge do escopo deste artigo. Sobre a plêiade de críticas encetadas contra a ponderação e os devidos contrapontos, checar ALMEIDA, L. 2014, p. 72-87; ALMEIDA, 2021, p. 150-180. 
adoção de um dever legal que Ihe era esperado, a exemplo de Prado (2008, p. 288-289). Portanto, conclui-se que não há, na proibição do defeito, em sentido naturalístico, uma relação causal de meio-fim. Sem embargo, é possível sustentar uma relação de meio-fim em amplo sentido (ALMEIDA, 2021, p. 317), na linha apregoada por Clérico.

Precisamente na etapa da legitimidade do fim, deve-se, pois, determinar qual o fim estatal. Na proibição do excesso, o fim embasará a ação positiva adotada pelo Estado na finalidade de restringir o direito fundamental, ao passo que, na proibição do defeito, o fim deverá justificar a omissão estatal. A par dessa diversidade de enfoque, na proibição do excesso nota-se que se reconhece ao Parlamento uma discricionariedade para selecionar todos os planos ou programas que não sejam vedados constitucionalmente. Logo, o fim não está de fato prescrito constitucionalmente. Ao revés, na proibição do defeito, o fim é definido de modo interpretativo e argumentativo por meio das normas do texto constitucional. Portanto, o objetivo estatal é determinável a partir dos enunciados normativos constitucionais (CLÉRICO, 2009, p. 330-331; ALMEIDA, 2019, p. 206; ALMEIDA, 2021, p. 317-340); o meio será a omissão total ou parcial que desprotege o direito fundamental, de sorte que, para que haja legitimidade do escopo estatal, essa omissão deve estar orientada pela preferência de investimento em ações de promoção ou proteção de outros direitos ou metas estatais (PULIDO, 2007, p. 806-811; ALMEIDA, 2021, p. 317-340).

No que tange à etapa de idoneidade, Clérico (2009, p. 330-335) sustenta um exame de idoneidade duplo para a proibição do defeito, conforme o tipo de omissão. Na hipótese de omissão parcial, é possível que o fim tenha coincidência total ou parcial com a satisfação de uma pretensão prestacional; na hipótese de omissão total, o fim pode ser a proteção desse direito prestacional ou outro objetivo qualquer. O crucial é que o meio será idôneo se fomentar ambos os fins (realização do direito prestacional e o outro fim estatal). Sem embargo, se a ideia de Clérico for interpretada no sentido de que seja possível juridicamente aceitar que exista um objetivo estatal de pura omissão e simplesmente rejeitar o cumprimento do dever de proteção do direito fundamental, ela deve ser rejeitada. A omissão só será legítima caso preste-se a ancorar a proteção ou promoção de terceiros direitos ou objetivos constitucionais, sob pena de ilegitimidade do fim e, consequentemente, desproporcionalidade (ALMEIDA, 2021, p. 317-340).

Ainda dentro desse compasso do subteste de idoneidade, deve-se cravar a posição de que a omissão pura ou total, inclusive de legislação que permita o cumprimento de deveres positivos, viola esse subteste, a conclamar a apreciação de inconstitucionalidade; se houver no mínimo algum tipo de legislação protetora do conteúdo do direito, isto é, se houver uma omissão parcial que conte com alguma normatização, avança-se para o próximo subteste, pois haveria idoneidade do meio (BARAK, 2012, p. 422-434; ALMEIDA, 2019, p. 206-207; ALMEIDA, 2021, p. 317-340).

No que tange ao subteste de necessidade, na estrutura da proibição do excesso, a missão do intérprete/ aplicador é visualizar se há alternativas que promovam a meta estatal na mesma intensidade do meio oficial e, concomitantemente, se elas são menos agressivas ao direito fundamental. No entanto, na proibição do defeito - considerando que não há uma relação meio-fim em sentido causal, mas um juízo normativo, efetuado pela instituição controladora, que considera afetado o direito fundamental por força da omissão ou ação insuficiente, a par da própria assimetria entre deveres positivos e negativos - não se exige do Estado o meio que mais proteja o direito fundamental. Ora, se na proibição do excesso o subteste da necessidade conclama uma opção menos lesiva do direito fundamental, na proibição do defeito almeja-se uma opção que proteja o direito em grau suficiente ou minimamente aceitável e, ao mesmo tempo, que promova o fim estatal na mesma medida (a proteção de terceiros direitos ou objetivos estatais), e não o meio alternativo que seja mais protetor do direito fundamental (CLÉRICO, 2009, p. 344-350; SILVA, 2012, p. 193-201; ALMEIDA, 2019, p. 206-207; ALMEIDA, 2021, p. 317-340). Obviamente, o Parlamento possui margem de conformação para proteger e promover o direito fundamental numa extensão maior do que a cobrada constitucionalmente, porém a omissão só será considerada se o direito fundamental carecer de proteção mínima ou no montante determinado. Muito útil na apreciação desse subteste é o conhecimento das leis orçamentárias, uma vez que será viável aferir alternativas que poderiam proteger mais o direito fundamental, mesmo que, como se explicou, não se busque a que tenha a maior eficácia protetiva.

No que diz respeito ao subteste de proporcionalidade em sentido estrito, é preciso salientar que haverá a dependência de argumentações práticas e avaliações empíricas, analíticas e normativas (PULIDO, 2007, p. 748758) para valorar os graus de afetação e de satisfação das posições, direitos e bens dispostos pelas normas em colisão, com especificação das posições jurídicas que estão diretamente em rota de colisão normativa (DUARTE, 2018, p. 52). 
No entanto, interessa notar que Alexy sugere uma modificação na sua "fórmula do peso"11, adaptando a estrutura da proporcionalidade para sindicar os deveres de proteção: ele incluiu agora uma segunda linha de valoração. No exame dos deveres negativos, avalia-se a intensidade de afetação do direito fundamental e valora-se o grau de satisfação trazido à meta estatal. No caso de deveres de proteção, uma linha de valoração é acrescida para examinar o direito fundamental em colisão com terceiros direitos ou metas estatais: a par do grau de proteção do direito fundamental, deve-se "calcular" o impacto da omissão dessa mesma medida (ALEXY, 2009, p. 66-84).

Ora, se o próprio Alexy reconhece a assimetria entre deveres positivos e negativos, como justificar a avaliação do impacto da omissão de alguma medida, considerando a gama de possibilidades de ação lícita confiadas ao poder controlado? A proposta desse jurista não seria reconhecer um oposto definitivo aos deveres de proteção, o que seria inviável justamente por essa assimetria?

Alexy justifica sua pretensão com a tese por ele denominada de "negação em cadeia" (ALEXY, 2009, p.66-84) - ver, também, Klatt e Meister (2014, p. 94-101).O impacto da omissão da medida protetiva é aferido pela valoração de uma opção menos protetora de forma imediata na escala de proteção formada pelas medidas opcionais em cotejo. Assim, há uma negação meramente relativa e não absoluta, pois ela se refere à medida menos protetiva seguindo a escala engendrada pelo intérprete/aplicador. Afinal, se houvesse somente a inversão da lógica da proibição do excesso para escrutinar o problema pelo parâmetro da proibição do defeito, o peso concreto seria considerado apenas como o grau de desproteção do direito fundamental. Destarte, já que se admite a assimetria entre os deveres negativos e positivos, é necessário introduzir essa segunda linha de avaliação para valorar o impacto da omissão da medida protetiva cotejada, já que, como já explicado, no que toca aos deveres negativos, toda e qualquer conduta positiva que possa causar o resultado vedado pela norma constitucional é prima facie proibida. Dessa forma, para os deveres positivos, não há uma única medida correlativa oposta.

No entanto, o critério proposto por Alexy depende do delineio argumentativo de alternativas à omissão adotada pelo Estado, o que é faticamente possível. Observa-se que Alexy sustenta que a primeira linha de valoração do peso concreto do direito fundamental do qual emana o dever positivo é o exame do grau de proteção conferido pela medida, enquanto que a segunda linha de valoração é a aferição do impacto da omissão dessa medida. Sem embargo, entende-se seria necessário um apuramento na proposta alexyana: em vez de indagar pelo grau de proteção conferido por essa medida, deve-se avaliar grau e intensidade de desproteção do direito fundamental gerado pela ação insuficiente ou pela omissão estatal. O impacto da omissão, por sua vez, indaga o que se pode evitar-se de prejuízo ao direito (ALMEIDA, 2019, p. 206-208; ALMEIDA, 2021, p. 317-340).

Para ilustrar a proposta, que se encampa neste texto, imagine um cenário hipotético em que várias crianças, residentes na zona rural, sejam transportadas para a escola na zona urbana da cidade, porém com um longo trajeto, cujo tempo de traslado possa ser superior à jornada escolar ${ }^{12}$. Em razão do prejuízo ao aprendizado, pode-se aquilatar uma violação prima facie ao conteúdo do direito fundamental à educação. O ente público responsável, por sua vez, justifica que não possui recursos para abrir escolas dentro da zona rural e que já gasta muito com transporte escolar, de sorte que investir mais no setor desfalcaria o fornecimento de alimentação aos estudantes. Portanto, há a configuração de um conflito normativo a envolver um direito à educação dessas crianças da zona rural com o direito à educação das demais crianças residentes na zona urbana, eis que haveria prejuízo, segundo o ente público, em atender a demanda da área rural em função do empobrecimento da merenda escolar.

Com efeito, partindo-se de uma versão de intensidade de controle mais débil, far-se-á uma avaliação bem sintetizada, com o intuito de ilustrar como devem ser aplicados os testes, marcando as diferenças com a proibição do excesso.

11 (ALEXY, 2002, p. 28-50). Com efeito, a ideia de uma equação não é, como o próprio jurista reconhece (2014, p. 55), para matematizar a ponderação, a sugerir uma precisão matemática e a dispensa de argumentação prático-moral, o que se está plenamente de acordo. De qualquer forma e justamente por isso, crê-se que é totalmente dispensável o emprego desse tipo de argumentação, isto é, reconstruir a aplicação do princípio da proporcionalidade por meio de algum tipo de fórmula aparentemente matemática. Assim, o exemplo hipotético trabalhado ao final do artigo, que envolve o conflito do direito à educação, prescindirá da adoção da fórmula do peso.

12 O exemplo desconsidera a existência de legislação que imponha um tempo máximo de transporte, algo já existente em alguns estados e municípios do país. Se houver regra jurídica que estipule um tempo máximo de transporte (por exemplo, 4 horas no total, contando a ida e a volta), não é o caso, a princípio, de utilizar a vertente da proibição do excesso, uma vez que há regra que densifica o conteúdo do direito fundamental e, desse modo, o comando de legalidade determina que se cumpra a lei, não sendo normalmente ativado um conflito normativo. Excepcionalmente, em caso de grave crise financeira e anomalia institucional, poder-se-ia avaliar eventual derrotabilidade da regra jurídica, a qual, se justificável, deve ser aceita só temporariamente e com cessação no menor tempo possível. Se, porém, o montante de tempo de transporte previsto pela regra fosse muito elevado, poder-se-ia justamente sindicar a constitucionalidade dessa norma pelo parâmetro da proibição do déficit, em virtude de uma situação de conflito normativo similar ao trabalhado no texto. 
No quadro telado, a omissão estatal baseia-se em uma motivação legítima (proteger o direito à educação dos outros alunos) e o meio também é adequado, pois, de fato, não há recursos para atender ambas as despesas.

O teste de necessidade procura um meio que promova o fim da mesma forma que o meio oficial e seja protetor em grau suficiente do direito fundamental. Deve-se, pois, cogitar alternativas que tenham esse condão. Como alternativas, considerem-se as seguintes: 1) abrir escolas em meio rural; 2) fornecer combustível aos pais, a fim de que eles mesmos façam o transporte; 3 ) consorciar-se com outros municípios, a fim de que as crianças estudem em outras sedes municipais mais próximas; 4) aumentar o número de linhas e de veículos que fazem o transporte, de modo a diminuir o tempo de trajeto. Dessas alternativas, o próprio município já rejeitou adotar a primeira e a última. As medidas foram enumeradas em ordem decrescente de eficácia protetiva, ou seja, a medida mais protetora ao direito à educação das crianças residentes na zona rural é a número 1 e a menos protetora é a número $4^{13}$.

Nesse ponto, é interessante observar a própria peça orçamental como argumento para verificar quais são as prioridades custeadas pelos cofres públicos. Imagine a situação hipotética em que esse mesmo município desembolse quantias consideráveis em propaganda institucional, festejos públicos ou até no asfaltamento de vias públicas. De qualquer forma, considerando a versão fraca da intensidade de controle que se adotou apenas para ilustrar o exemplo, não haveria meios opcionais que satisfizessem os requisitos desse teste, o que levaria ao último subteste, o da proporcionalidade em sentido estrito. Obviamente, uma conclusão definitiva dependeria de maiores dados empíricos, porquanto, eventualmente, a opção 3 poderia justificar um juízo de desproporcionalidade por proibição do defeito pela reprovação na etapa da necessidade, a justificar a censura judicial. Isso ocorreria caso a adoção da opção 3 não conclamasse aporte de recursos acima do que já desembolsa para fazer esse transporte e o tempo de trajeto para o município vizinho fosse razoável.

$\mathrm{Na}$ etapa da proporcionalidade em sentido estrito, realizar-se-ia uma ponderação que pudesse resolver o conflito de modo mais equilibrado. Ora, se há prioridade absoluta no tratamento de crianças e adolescentes (art. 227, caput, Constituição Federal), isso representa afirmar que existe um peso abstrato maior nas posições protegidas pelo direito à educação. Sem embargo, a justificação estatal também se ampara na promoção do direito à educação para outras crianças, o que, nesse panorama, traria posições jurídicas em confronto que, à partida, teriam a mesma importância social.

O peso concreto, na ótica do objetivo estatal, é o grau de satisfação dado ao bem ou direito privilegiado. Já no caso do direito fundamental que se escrutina pela vertente da proibição de defeito (direito à educação das crianças em zona rural), com as duas linhas de valoração examinam-se a intensidade de desproteção e, também, o impacto da omissão, isto é, o que se pode evitar de prejuízo. A segunda linha de valoração ajuda a definir o raciocínio ponderativo, tendo em vista que, sem ela, normalmente haveria empates argumentativos entre a intensidade de afetação do direito fundamental e a intensidade de satisfação da meta estatal, algo que beneficia a instância controlada por suscitar maior deferência nessa hipótese.

Se a intensidade de desproteção tem uma força robusta, tal como possuem os interesses e direitos privilegiados pelo ente público, a aferição do que se pode evitar de prejuízo, retomando as alternativas lançadas alhures, implica a análise dessas alternativas e sua comparação com o meio oficial. A visualização da peça orçamentária, a par de indicar outros direitos ou interesses já fomentados pelo ente público, ajuda na ponderação para concluir se a justificação dada por ele é aceitável.

Dentro do cenário hipotético, formulado de modo objetivo e simples no intuito de demonstrar a aplicação da norma da proporcionalidade na faceta de proibição do defeito, é possível descartar as alternativas 1 e 2 , uma vez que, como explicado, não se busca a maior proteção possível, mas sim um grau de proteção suficiente. Entre a omissão verificada e as alternativas 3 e 4 , a ponderação que se faz dá mais força a essas opções do que autorizar a manter o nível de proteção atualmente oferecido, que é deficitário. Afinal, o serviço de transporte escolar não tem trazido resultado sério para auxiliar no aprendizado dos pueris seres, haja vista que é inviável esperar que o aluno, desgastado pela longa jornada de transporte, tenha condição de aprender efetivamente. Essa conclusão

13 Obviamente, aqui é necessária uma avaliação empírica e analítico-normativa para fazer essa assertiva, o que reclamaria maiores dados para aferir a realidade. De qualquer sorte, entende-se que a medida 1 é a mais protetora, ainda que comparada à medida 2 , uma vez que o tempo de distância seria menor de trajeto a princípio, a par de manter-se mais próximo da família. Entre as medidas 3 e 4 há muita similaridade do nível de proteção e a coleta de mais dados empíricos poderia justificar uma inversão na ordem. 
só se agiganta num cenário em que a peça orçamental indique o investimento de recursos públicos em despesas de menor importância social, como a feita em propaganda institucional ou no custeio de festejos públicos ${ }^{14}$. Dessa forma, como é cediço, a conclusão da instituição julgadora não renega a possibilidade de o município, se quiser, avançar no patamar de proteção conferido.

Agora se examina uma classe de problemas concretos examinada pelo Supremo Tribunal Federal, relativo ao fornecimento de medicamentos experimentais como forma de proteger o direito à saúde. Com efeito, a Corte já chegou a considerar válida a imposição ao ente público em reembolsar despesas com tratamento experimental em outro país de doença incurável (retinose pigmentar) no Recurso Extraordinário n. 368.564/DF, tendo o veredito salientado a prevalência do direito à saúde sobre questões financeiras. Logo, seria factível supor que, a prevalecer essa inteligência, seria possível obrigar o Estado a fornecer medicamentos experimentais.

Contudo, em dois precedentes posteriores, o Supremo Tribunal Federal reverteu sua jurisprudência. E no julgamento da Ação Direta de Inconstitucionalidade n. 5.501/DF, embora não tenha estruturado a ponderação com base na proporcionalidade, o Tribunal terminou por reconhecer a inconstitucionalidade da Lei Federal n. 13.269/16, que permitia a entrega de fosfoetanolamina sintética ${ }^{15}$ a pacientes diagnosticados com neoplasia maligna, fármaco sem aprovação da Agência Nacional de Vigilância Sanitária quanto à segurança e à eficiência. Já no Recurso Extraordinário n. 657.718/MG, em que se debatia especificamente a viabilidade de cominação a entes públicos de obrigação de fornecer medicamentos não registrados na ANVISA, a par da tese fixada, a Corte enfatizou a proibição de condenação estatal ao fornecimento de drogas experimentais ${ }^{16}$. Sendo assim, nesse tipo de situação, haveria déficit de proteção ao direito à saúde?

A estruturação do raciocínio decisório pela metódica da proporcionalidade auxiliaria muito a tomada de decisão, pois, além de fornecer maior clareza analítica, evitaria que o julgador efetuasse valorações desnecessárias. Como mencionado, na Ação Direta de Inconstitucionalidade n. 5.501/DF, o argumento central do Supremo Tribunal Federal foi de que a deliberação sobre a eficácia, acurácia e segurança de medicamento demandava expertise técnica, o que seria assunto confiado à competência do Executivo e não do Legislativo. Logo, segundo o Supremo Tribunal Federal, a Lei 13.269/16 padecia de vício de violação à separação de poderes, não tendo sido identificado aí nenhum conflito normativo. Porém, é inequívoco que esse fundamento não é exato, uma vez que a Constituição é cristalina em conferir a competência legislativa concorrente para o Legislativo Federal elaborar leis sobre proteção e defesa da saúde (art. 24, XII).

Nesse contexto, identifica-se o conflito normativo entre o direito à saúde, na dimensão individual daqueles que estão enfermos, cuja promoção era o objetivo da Lei 13.269/16, e o próprio direito à saúde, mormente na sua dimensão coletiva, mas também na individual. Diante da importância dos direitos em jogo, pode-se mesmo partir de uma intensidade de controle judicial mais enfraquecida.

Conquanto ao fim de promover a saúde dos enfermos da neoplasia maligna seja legítimo e mesmo que se adote uma intensidade de controle judicial mais débil, a medida estatal reprova no teste de proporcionalidade já na etapa da idoneidade. Afinal, não há comprovação clínica e respaldo da ciência médica de que o fármaco ou o tratamento são eficazes em curar, debelar ou diminuir os sintomas deletérios da moléstia, sequer sendo preciso avançar nos demais subtestes. Ora, a proteção e a defesa da saúde pública, sejam consideradas mero interesse público ou mesmo na dimensão coletiva do direito à saúde, impõem ao Estado o controle da produção, comercialização, distribuição e experimentação de drogas e equipamentos, insumos, bens e serviços de saúde, tanto para zelar que sejam aptos e eficazes ao que se propõem como para prevenir danos à saúde da população.

Assim, em realidade, as medidas trazidas pela Lei 13.269/16 consubstanciam fundamentalmente a violação da dimensão coletiva do direito à saúde, em função da desproporcionalidade das regras legais que incluíram um medicamento sem comprovação de idoneidade para o tratamento do câncer, após prévio conflito normativo entre

14 Como fica evidente, portanto, se as despesas privilegiadas no orçamento não demonstrarem menor importância social e caso realmente haja uma penúria capaz de alicerçar outro resultado ponderativo, a omissão municipal estará justificada e, portanto, não há desproporcionalidade.

15 A fosfoetanolamina sintética é uma substância química descoberta nos anos 70 do século passado e foi empregada em testes com camundongos para o enfrentamento do melanoma. Em pesquisas lideradas por universidades, foi testada nas fases iniciais em humanos voluntários, após prévia fase de experimentos em culturas de células e em pequenos animais, mas ainda não conta com estudos conclusivos quanto à eficácia e à segurança para os seres humanos. Progressivamente várias ações judiciais começaram a ser propostas para que o Estado prestasse indiscriminadamente essa substância aos portadores de câncer, até que o Legislativo resolveu legislar sobre.

16 Especificamente sobre este acórdão, remete-se a ALMEIDA, 2019, p. 208-224, e ALMEIDA, 2021, p. 505-520, razão pela qual o texto do artigo centrar-se-á na fundamentação dada na ADIn n. 5.501/DF.Conferir, também, ALMEIDA, 2021, p. 475-476, em relação ao tema da fosfoetanolamina. $\mathrm{Na}$ defesa da tese de que tratamentos experimentais reprovam no teste de idoneidade, ALMEIDA, 2019, p. 211. 
o direito à saúde dos doentes de câncer, tanto na sua dimensão individual, quanto na dimensão coletiva. Aliás, pode-se mesmo pensar que há um conflito interno entre a própria dimensão individual do direito à saúde desses enfermos, pois o remédio poderia ser inseguro para a pretensão de melhora em sua saúde. Ademais, a depender do custo dessa droga, poder-se-ia visualizar mais claramente a conflituosidade com o direito à saúde de outros titulares, caso os tratamentos não pudessem ser oferecidos em função de realocação de despesas para fazer cumprir a obrigação imposta em lei. Dessa forma, com a reprovação no teste de idoneidade, sequer seria preciso avançar para os demais, o que reforça a utilidade da estruturação do raciocínio judicial pela norma da proporcionalidade para avaliar a suficiência de tutela ao direito fundamental.

O uso do parâmetro de controle da proibição do defeito permitirá, consoante uma prática constitucional estável, formar uma sistematização de "regras-resultado" de ponderação, as quais permitirão, também, categorizar a jurisprudência, o que, em relação aos direitos fundamentais sociais, pode ser visto como uma formatação do conteúdo mínimo desses direitos, a aumentar a intensidade de justificação do ente estatal sempre que pretender justificar validamente a omissão em relação a determinada pretensão integrante do minimum $\operatorname{core}^{17}$ desses direitos (ALMEIDA, L. 2014, p. 245-262).

Tecidas as modificações necessárias ao exame de proporcionalidade para controlar a suficiência de proteção estatal, é preciso frisar que a busca da justificação estatal para a não proteção ou tutela deficitária por meio da norma da proporcionalidade termina por reforçar um diálogo interinstitucional entre os encarregados das funções legislativas, executivas e judiciais, o que enseja uma procura incessante de legitimação da instância judiciária para bem atuar nesse mister; o uso contínuo e sistemático dessa ferramenta heurística, complementado pelas contribuições críticas da doutrina, permitirá seu aperfeiçoamento e o consequente desenho mais claro do conteúdo garantido pela norma de um direito fundamental social na sua dimensão positiva (e, acrescenta-se, o mesmo vale para as dimensões positivas dos direitos fundamentais de liberdade), o que termina por ser a opção mais protetora e mais racional ao escrutínio desses direitos (CONTIADES; FOTIADOU, 2012, p. 662-686).

\section{Oâmbito de aplicação da proibição do defeito: articulação com a proibição do excesso?}

Como já se infere das colocações anteriores, o objeto da proibição do defeito é uma omissão. Porém, como é cediço para quem estuda o direito constitucional, a distinção entre uma ação e uma omissão nem sempre é clara e haverá zonas nebulosas onde essa distinção ficará obscurecida (MIRANDA, 2012, p. 702-707; MENDES, 2007, p. 385-387).

Ora, se é pressuposta uma dimensão positiva (deveres ativos) e uma negativa (deveres negativos) a todos os direitos fundamentais em razão do seu tratamento dogmático unitário, cingindo-se o debate agora apenas aos direitos sociais, percebe-se que a dimensão negativa desses direitos exige tanto a abstenção estatal para não turvar o acesso a bens e prestações de cunho social almejados e alcançados pelo próprio indivíduo por suas próprias forças, como também o não retrocesso estatal no fornecimento desses bens aos cidadãos, seja no aspecto quantitativo ou qualitativo, a consubstanciar o que alguns chamam da tese da vedação de retrocesso social ${ }^{18}$. Por sua vez, a dimensão positiva refere-se justamente a bens e prestações exigíveis do Estado por força de uma aplicabilidade imediata das próprias normas de direitos fundamentais, sem a necessidade absoluta de concreção dessas prestações em normas infraconstitucionais.

Como se intui sem dificuldade, o primeiro aspecto da dimensão negativa dos direitos fundamentais sociais não está no âmbito ou no objeto da proibição do déficit, de sorte que o controle efetua-se pelo uso da proibição do excesso. Da mesma forma, aplica-se a proibição do defeito para apurar eventual violação à dimensão positiva dos direitos fundamentais sociais.

17 Consoante posição defendida em ALMEIDA, L.2014, p. 245-262, o conteúdo ou núcleo mínimo serve como padrão que parametriza e categoriza a jurisprudência constitucional dos direitos sociais. Se estiverem em debate prestações definidas no conteúdo mínimo, haverá maior fardo de argumentação e de prova a cargo do Estado para justificar a não prestação; se não houver justificação legítima, devem ser fornecidas. Obrigações fora do núcleo mínimo, por sua vez, propiciarão um controle mais enfraquecido e com menores ônus de justificação e de prova atribuíveis ao ente público. Com isso, o núcleo mínimo assegura maior estabilização e segurança jurídica, fornece maior orientação às instâncias inferiores e ostenta autonomia dogmática em relação à norma daproporcionalidade, a funcionar como um padrão adicional que norteará as ponderações futuras.

18 Particularmente, não se concede autonomia dogmática à tese da vedação de retrocesso social, pois o que é essencial é o controle de proporcionalidade da omissão que afeta prima facie o direito fundamental. 
A indagação maior é verificar qual o parâmetro de controle utilizável para retrações do Estado no nível de proteção conferido a determinado direito fundamental social, ou seja, para o segundo aspecto da dimensão negativa dos direitos fundamentais sociais. Isto é, há uma normatização e o fornecimento de prestações estatais aos indivíduos, mas pretende o Estado recuar no fornecimento dessas prestações. Essa hipótese configura uma ação ou, mais propriamente, uma omissão a ser controlada? Aplica-se a proibição do excesso ou a proibição do defeito?

A retrocessão nas prestações estatais não são propriamente omissões, mas ações. Porém, o essencial para elucidar o problema é verificar se houve um resquício de proteção, ou seja, se, embora tenha regredido quantitativa ou qualitativamente no fornecimento de prestações, ainda remanesce algum tipo de prestação ou proteção conferida aos titulares do direito ou se houve a pura e simples revogação das prestações ou extinção das instituições estatais, sem deixar nenhuma alternativa ou compensação aos então titulares do direito fundamental. Na primeira hipótese, justifica-se a adoção do parâmetro da interdição do defeito, pois ainda é fornecido algum tipo de proteção ao conteúdo do direito fundamental, o que reclama a apreciação da suficiência da proteção restante. No segundo caso, ao revés, como não se deixou nenhum tipo de alternativa protetiva ao titular do direito e retiraram-se prestações que materializavam a densificação do conteúdo do direito fundamental por anterior ação do legislador, conclama-se a aplicação da proibição do excesso para ver se o retrocesso é constitucionalmente válido (CLÉRICO, 2009, p. 328-329).

Por conseguinte, se os âmbitos de aplicação da proibição do excesso e do defeito são distintos e se a estrutura dos testes não é congruente integralmente, como aqui sustentado, a inferência a que se chega é de que os resultados fornecidos pela proibição do excesso e pela proibição do defeito não coincidem. Sem embargo, se é essa a conclusão, restam duas reflexões a fazer. Existe alguma articulação entre a proibição do excesso e a proibição de insuficiência? Nesse prisma, se as duas vertentes do controle de proporcionalidade entrassem em choque, qual haveria de prevalecer? Isto é, seria imaginável que uma medida seja julgada desproporcional pelo excesso, mas proporcional pela vedação de insuficiência de tutela ou vice-versa? Qual o resultado prevaleceria (CANAS, 2012, p. 872-873)?

As linhas pretéritas deixaram as balizas para a resposta dessas indagações. Entrementes, o que ocorre não é propriamente um conflito entre a proibição do excesso e a proibição do defeito, eis que são duas perspectivas de proporcionalidade diversas, portanto, a serem utilizadas para resolver diferentes problemas. Deveras, se - Parlamento possui uma margem de discricionariedade ou conformação para legislar sobre os assuntos importantes, não exaurindo sua função a ser um mero executor da constituição, torna-se perceptível que, entre o que é exigido constitucionalmente a título de proteção a um direito fundamental e aquilo que é vedado por ser excessiva interferência na esfera de um direito fundamental, existe um "corredor" de discricionariedade que deve ser respeitado pela instituição que exercita o controle de constitucionalidade. Equivale dizer que os patamares mínimos de proteção demandados pelas normas jusfundamentais e as balizas máximas de restrição impostas também por essas normas não se cruzam nem se confundem (SILVA, 2012, p. 192).

Logo, é perfeitamente possível a utilização de ambos os testes de proporcionalidade em um quadro em que seja necessário avaliar as duas perspectivas; não há risco de incompatibilidade no resultado do veredito, eis que é a mesma instituição que realizará o controle pelos testes, sob pena de contradição lógica. Destarte, não pode uma norma ou medida estatal ser simultaneamente insuficiente e excessiva em relação a um mesmo direito fundamental.

Poder-se-ia obtemperar a possibilidade de haver uma divergência se a perspectiva de avaliação estivesse dirigida para diferentes direitos fundamentais. De fato, nessa situação é possível que uma norma ou medida seja, em relação a um direito $A$, (des)proporcional por excesso, ao passo que também será (des)proporcional por tutela insuficiente do direito $B$. Porém, mesmo assim não se pode falar de incompatibilidade, sejam quais forem as combinações de resultado possíveis: se houver proporcionalidade na perspectiva que interdita o excesso e na da que proscreve a tutela deficitária, a norma é válida; se houver desproporcionalidade por excesso, mas proporcionalidade na proteção conferida, haverá desproporcionalidade na vertente da proibição do excesso; se houver proporcionalidade no exame da proibição do excesso, mas houver desproporcionalidade na omissão, haverá censura pelo parâmetro da proibição do defeito.

Problema diferente e que não envolve qualquer conflito entre essas duas perspectivas diversas de proporcionalidade está na verificação de que determinada medida, por ser desproporcional por excesso ao direito A, configura uma proteção suficiente do direito B. Com o veredito de desproporcionalidade e eventual aplicação da sanção de nulidade, poderia o direito B ficar carente de proteção suficiente. Obviamente, caso a omissão perpetue- 
se por tempo relevante, será possível um futuro exame de proporcionalidade, dessa vez para avaliar a omissão em não editar novos atos normativos e ações que pudessem proteger o direito minimamente. De qualquer forma, muito provavelmente a instância aplicadora, para diminuir as consequências resultantes ao direito $B$, efetuaria um juízo ponderativo para graduar a sanção pela inconstitucionalidade, por exemplo, em vez de aplicar a nulidade, usar alguma técnica, como a interpretação conforme ou até mesmo limitar a eficácia da decisão para algum momento futuro sem retroagir à data de edição da medida. Seja como for, essas cautelas não envolvem a aplicação do princípio da proporcionalidade em qualquer de suas vertentes ${ }^{19}$.

\section{Conclusões}

O princípio da proporcionalidade pode sindicar a omissão parcial ou total do Estado. Porém, há uma assimetria entre os deveres negativos e positivos, o que implica a necessidade de algumas modificações na estrutura da proporcionalidade na vertente da proibição do defeito.

Já na proibição do defeito, há uma relação meio-fim de natureza normativa. Os fins serão legítimos se estiverem previstos na constituição. Os meios serão adequados se promoverem outros direitos ou interesses públicos constitucionalmente previstos. A omissão será necessária se não houver alternativas que promovam os terceiros direitos ou interesses públicos no mesmo patamar e, concomitantemente, protejam em grau suficiente (e não no grau mais protetivo possível) o direito fundamental. No teste de proporcionalidade em sentido estrito, acrescenta-se uma segunda linha de valoração para examinar o peso concreto do direito fundamental, com exame, em grau decrescente, das medidas protetivas alternativas.

E, por fim, a proporcionalidade por proibição do defeito tem como objeto a dimensão positiva dos direitos fundamentais e inclui a dimensão negativa caso haja retrocesso quantitativo ou qualitativo no fornecimento de prestações, desde que seja ofertada uma alternativa de proteção desse direito. Dessa forma, a proibição do excesso e a proibição de defeito não conflitam entre si, pois são usadas para problemas distintos, não havendo incompatibilidade sob pena de contradição lógica.

\section{Referências}

ACHEAMPONG, Kenneth Asamoa. Reforming the substance of the African Charter on Human and Peoples' rights: civil and political rights and socio-economic rights. African Human Rights Law Journal, Pretória, v. 1, n. 2, p. 185-204, 2001.

\section{ALEXANDRINO, José de Melo. A estruturação do sistema de direitos, liberdades e garantias na Constituição portuguesa de 1976. Coimbra: Almedina, 2006.}

ALEXANDRINO, José de Melo. A indivisibilidade dos direitos do homem à luz da dogmática constitucional. In: ALEXANDRINO, José de Melo. O discurso dos direitos. Coimbra: Coimbra Editora, 2011. p. 179-203.

ALEXY, Robert. Constitutional rights and proportionality. Revus, Kranj, v. 22, p. 51-65, 2014. Disponível em: https://journals.openedition.org/revus/2783. Acesso em: 17 jun. 2016.

ALEXY, Robert. Epílogo a la teoría de los derechos fundamentales. Tradução: Carlos Bernal Pulido. Revista Española de Derecho Constitucional, Madrid, año 22, n.66, p. 13-64, sept. /dic. 2002.

ALEXY, Robert. Sobre los derechos constitucionales a protección. In: MANRIQUE, Ricardo García (ed.). Derechos sociales y ponderación. 2. ed. Madrid: Fundación Coloquio Jurídico Europeo, 2009. p. 45-84.

\footnotetext{
19 Philippe (1990, p. 7-14) diferencia um controle de proporcionalidade do princípio da proporcionalidade. O primeiro abrange o segundo, mas o segundo não é equivalente ao primeiro. No controle de proporcionalidade, examina-se a ideia de equilíbrio ou razoabilidade que está incrustada na própria norma, a qual será reexaminada por outra instituição. O caso do art. 59 do Código Penal é um exemplo de um controle de proporcionalidade no sentido dado por Philippe, sem envolver a aplicação de um princípio de proporcionalidade, que se ativa caso hajaum conflito normativo não sanável por metanormas de conflito e que implica a apreciação do problema na estrutura fornecida pelos diversos subtestes. No caso da regra de dosimetria referida, ela estabelece critérios para calcular a pena de modo "proporcional" ao ilícito praticado. No sentido dado por Philippe, parece correto que as técnicas referidas no corpo do artigo consubstanciariam apenas um exame ou controle de proporcionalidade nessa ideia mais dilatada, mas não se trata de aplicação do princípio da proporcionalidade.
} 
ALEXY, Robert. Teoria dos direitos fundamentais. Tradução: Virgílio Afonso da Silva. São Paulo: Malheiros, 2008.

ALMEIDA, Kellyne Laís Laburú Alencar de. O paradoxo dos direitos fundamentais. Porto Alegre: Sergio Antonio Fabris, 2014.

ALMEIDA, Luiz Antônio Freitas de. O princípio da separação de poderes e direitos fundamentais sociais: a necessidade de releitura sob a ótica de um Estado Social de Direito. Revista de Direito Constitucional e Internacional, São Paulo, v. 19, n. 77, p. 185-206, out./dez. 2011.

ALMEIDA, Luiz Antônio Freitas de. A judicialização do direito à saúde e a norma da proporcionalidade: o problema dos medicamentos e serviços não incorporados ao Sistema Único de Saúde e dos medicamentos sem registro na Agência Nacional de Vigilância Sanitária. Direito, Estado e Sociedade, Rio de Janeiro, n. 55, p. 197-230, jul./dez. 2019. Disponível em: http://direitoestadosociedade.jur.puc-rio.br/cgi/cgilua.exe/sys/start.htm ?infoid=409\&post\%5Fdata=user\%3Dnil\%26UserActiveTemplate\%3Dnil\%26sid\%3D38\&sid=38. Acesso em: 12 jan. 2021.

ALMEIDA, Luiz Antônio Freitas de. A tutela "ponderada" do direito à saúde: proporcionalidade e seu uso na defesa contra a insuficiência de proteção estatal. Belo Horizonte: Fórum, 2021.

ALMEIDA, Luiz Antônio Freitas de. Direitos fundamentais sociais e ponderação: ativismo irrefletido e controle jurídico racional. Porto Alegre: Sergio Antonio Fabris, 2014.

BARAK, Aharon. Proportionality: constitutional rights and their limitations. Tradução: Doron Kalir. Cambridge: Cambridge University Press, 2012.

BOBBIO, Norberto. A era dos direitos. Tradução: Carlos Nelson Coutinho. Rio de Janeiro: Elsevier, 2004.

BÖCKENFÖRDE, Ernest-Wolfgang. Los derechos fundamentales sociales en la estructura de la constitución. In: BÖCKENFÖRDE, Ernest-Wolfgang. Escritos sobre derechos fundamentales. Tradução: Juan Luís Requeijo Pagés; Ignácio Villaverde Menédez. Baden-Baden: Nomos Verlagsgesellschaft, 1993. p. 72-83.

BÖCKENFÖRDE, Ernest-Wolfgang. Sobre la situación de la dogmática de los derechos fundamentales tras 40 años de Ley Fundamental. In: BÖCKENFÖRDE, Ernest-Wolfgang. Escritos sobre derechos Fundamentales. Tradução: Juan Luís Requeijo Pagés; Ignácio Villaverde Menédez. Baden-Baden: Nomos Verlagsgesellschaft, 1993. p. 95-137.

BOUSTA, Rhita. La "spécifité" du contrôle constitutionnel français de proportionnalité. Revue Internationale de Droit Comparé, Paris, v. 59, n.4, p. 859-877, 2007.

CANARIS, Claus-Wilhelm. Direitos fundamentais e direito privado. Tradução: Paulo Mota Pinto; Ingo Wolfgang Sarlet. Coimbra: Almedina, 2009.

CANAS, Vitalino. A proibição de excesso como instrumento mediador de ponderação e optimização (com incursão na teoria das regras e dos princípios). In: SOUSA, Marcelo Rebelo de; QUADROS, Fausto; OTERO, Paulo (coord.). Estudos em homenagem ao Prof. Doutor Jorge Miranda. Lisboa: Faculdade de Direito da Universidade de Lisboa; Coimbra: Coimbra Editora, 2012. v. 3, p. 811-894.

CANAS, Vitalino. Constituição prima facie: igualdade, proporcionalidade, confiança (aplicados ao "corte" de pensões). E-pública - Revista Electrônica de Direito Público, Lisboa, v.1, n. 1, p. 1-41, jan. 2014. Disponível em: https://www.e-publica.pt/volumes/v1n1a01.html. Acesso em: 12 jan. 17.

CANAS, Vitalino. O princípio da proibição do excesso na conformação e no controlo de atos legislativos. Coimbra: Almedina, 2017.

CLÉRICO, Laura. El examen de proporcionalidad en el derecho constitucional. Buenos Aires: Facultad de Derecho de Buenos Aires/EUDEBA, 2009. (Serie tesis) 
CONTIADES, Xenophon; FOTIADOU, Alkmene. Social rights in the age of proportionality: global economic crisis and constitutional litigation. International Journal of Constitutional Law, Oxford, v. 10, n. 3, p. 660-686, july 2012.

DUARTE, David. Drawing up the boundaries of normative conflicts that lead to balances. In: WORLD CONGRESS OF THE INTERNATIONAL ASSOCIATION FOR PHILOSOPHY OF LAW AND SOCIAL PHILOSOPHY (IVR), 24, 2009, Beijing. Annals [...]. Stuttgart: Franz Steiner Verlag; Nomos, 2010. p. 51-62.

DUARTE, David. Gains and losses in balancing social rights. In: DUARTE, David; SAMPAIO, Jorge Silva (ed.). Proportionality in law: an analytical perspective. Cham: Springer, 2018. p. 49-70.

DUARTE, David. Rebutting defeasibility as operative normative defeasibility. In: D'ALMEIDA, Luís Duarte et al. (coord.). Liber Amicorum de José de Souza Brito em comemoração do $70^{\circ}$ aniversário. Lisboa: Almedina, 2009. p. 161-174.

FORSTHOFF, Ernst. Concepto y esencia del Estado Social de Derecho. In: ABENDROTH, Wolfgang; FORSTHOFF, Ernst; DOEHRING, Kar. EI Estado Social. Tradução: José Puente Egídio. Madrid: Centro de Estudios Constitucionales, 1986. p. 69-106.

GARCIA, Emerson. Princípio da separação dos poderes: os órgãos jurisdicionais e a concreção dos direitos sociais. Revista da Faculdade de Direito da Universidade de Lisboa, Lisboa, v. 46, n. 2, p. 955-1.003, 2005.

GRIMM, Dieter. Proportionality in canandian and german constitutional jurisprudence. University of Toronto Law Journal, Toronto, v. 57, n. 2, p. 383-397, jan. 2007.

KLATT, Mathias; MEISTER, Moritz. The constitutional structure of proportionality. Oxford: Oxford University Press, 2014.

LOEWENSTEIN, Karl. Teoría de la constitución. Tradução: Alfredo Gallego Anabitarte. Barcelona: Ariel, 1982.

MARTINS, Leonardo. Introdução à jurisprudência do Tribunal Constitucional Federal alemão. In: SCHWABE, Jürgen. Cinqüenta anos do Tribunal Constitucional Federal Alemão. Montevideo: Konrad-Adenauer-Stiftung E. V., 2005. p. 33-126.

MATOS, André Salgado de. O direito ao ensino: contributo para uma dogmática unitária de direitos fundamentais. In: MIRANDA, Jorge et al. (org.). Estudos em homenagem ao Professor Doutor Paulo de Pitta e Cunha. Coimbra: Almedina, 2010. v. 3, p. 395-470.

MEDEIROS, Rui. Direitos, liberdades e garantias e direitos sociais: entre a unidade e a diversidade. In: MIRANDA, Jorge (coord.). Estudos em homenagem ao Prof. Doutor Sérvulo Correia. Lisboa: Faculdade de Direito da Universidade de Lisboa; Coimbra: Coimbra Editora, 2010. v. 1, p. 657-683.

MENDES, Gilmar Ferreira. Jurisdição constitucional: o controle abstrato de normas no Brasil e na Alemanha. 5. ed. São Paulo: Saraiva, 2007.

MICHELMAN, Frank. The constitution, social rights, and liberal political justification. International Journal of Constitutional Law, Oxford, v. 1, n. 1, p. 13-34, jan. 2003.

MIRANDA, Jorge. A fiscalização da inconstitucionalidade por omissão. In: MIRANDA, Jorge et al. (org.). Estudos em homenagem a Miguel Galvão Teles. Coimbra: Almedina, 2012. p. 687-716.

NABAIS, José Casalta. Algumas reflexões críticas sobre os direitos fundamentais. In: VARELA, Antunes et al. (org.). Ab Vno Ad Omnes: 74 anos da Coimbra Editora 1920-1995. Coimbra: Coimbra Editora, 1998. p. 9651.004 .

NOVAIS, Jorge Reis. As restrições aos direitos fundamentais não expressamente autorizadas pela constituição. Coimbra: Coimbra, 2003.

NOVAIS, Jorge Reis. Direitos sociais: teoria jurídica dos direitos sociais enquanto direitos fundamentais. Coimbra: Coimbra: Wolters Kluwer, 2010. 
NOVAIS, Jorge Reis. Os princípios constitucionais estruturantes da república portuguesa. Coimbra: Coimbra Editora, 2011.

PAVCNIK, Marijan; LACHMAYER, Friedrich. The principle of proportionality (theses for discussion). In: WORLD CONGRESS OF THE INTERNATIONAL ASSOCIATION FOR PHILOSOPHY OF LAW AND SOCIAL PHILOSOPHY (IVR), 24, 2009, Beijing. Annals [...]. Stuttgart: Franz Steiner Verlag; Nomos, 2010. p. 161-167.

PHILIPPE, Xavier. Le contrôle de proportionnalité dans le jurisprudence constitutionnelle et administrative françaises. Paris: Economica : Presses Universitaires d'Aix-Marseille, 1990.

PIEROTH, Bodo; SCHLINK, Bernhard. Direitos fundamentais: direito estadual II. Tradução: António C. Franco; António Francisco Souza. Lisboa: Universidade Lusíada, 2008.

PIRKER, Benedikt. Proportionality analysis and models of judicial review: a theoretical and comparative study. Groningen: Europa Law Review, 2013.

PRADO, Luiz Regis. Curso de direito penal brasileiro. 8. ed. São Paulo: Revista dos Tribunais, 2008. v. 1.

PULIDO, Carlos Bernal. El principio de proporcionalidad y los derechos fundamentales. 3. ed. Madrid: Centro de Estudios Políticos y Constitucionales, 2007.

RIVERS, Julian. Proportionality and variable intensity of review. Cambridge Law Journal, Cambridge, v. 65, n. 1, p. 174-207, mar. 2006.

ROIG, F. Javier Ansuátegui. Argumentos para una teoría de los derechos sociales. In: ZAPATERO, Virgilio; GÓMES, Maria Isabel Garrido (ed.). Los derechos sociales como una exigencia de la justicia: cuadernos de la cátedra de democracia y derechos humanos. Madrid: Universidad de Alcalá, 2009. p. 143-163.

SARLET, Ingo Wolfgang. A eficácia dos direitos fundamentais. 8. ed. Porto Alegre: Livraria do Advogado, 2007.

SARLET, Ingo Wolfgang. Eficácia e efetividade do direito à moradia na sua dimensão negativa (defensiva): análise crítica à luz de alguns exemplos. In: SOUZA NETO, Cláudio Pereira; SARMENTO, Daniel (org.). Direitos sociais: fundamentos, judicialização e direitos sociais em espécie. Rio de Janeiro: Lumen Juris, 2010. p. 1.019-1.049.

SCHWABE, Jürgen. Cinqüenta anos de jurisprudência do Tribunal Constitucional Federal alemão. Tradução: Beatriz Hennig et al. Montevideo: Konrad-Adenauer-Stiftung E. V., 2005.

SILVA, Jorge Pereira da. Interdição de protecção insuficiente, proporcionalidade e conteúdo essencial. In: SOUZA, Marcelo Rebelo; QUADROS, Fausto de; OTERO, Paulo; PINTO, Eduardo Vera-Cruz (coord.). Estudos de Homenagem ao Prof. Doutor Jorge Miranda: Direito Constitucional e Justiça Constitucional. Lisboa: Faculdade de Direito da Universidade de Lisboa; Coimbra: Coimbra Editora, 2012. v. 2, p. 185-210.

SILVA, Vasco Pereira da. "Todos diferentes, todos iguais" - Breves considerações acerca da natureza jurídica dos direitos fundamentais. In: DIREITO e Justiça: estudos em homenagem ao Professor Doutor Luís Alberto de Carvalho Fernandes. Lisboa: Universidade Católica Editora, 2011. v. 3, p. 553-583.

SILVA, Virgílio Afonso da. Direitos fundamentais: conteúdo essencial, restrições e eficácia. São Paulo: Malheiros, 2009.

SWEET, Alec Stone; MATHEWS, Jud. Proportionality balancing and global constitutionalism. Columbia Journal of Transnational Law, New York, v. 47, n. 1, p. 73-165, dec. 2008.

VIDAL, Andrea de Barroso Silva Fragoso. A norma da proporcionalidade: algumas controvérsias doutrinárias. In: DUARTE, David; SARLET, Ingo Wolfgang; BRANDÃO, Paulo de Tarso (org.). Ponderação e proporcionalidade no Estado constitucional. Rio de Janeiro: Lumen Juris, 2013. p. 261-306.

Recebido em: 02.06.2020

Aceito em: 23.06.2021 